The Korean Journal of Parasitology

Vol. 39, No. 1, 1-11, March 2001

Mini-Review

\title{
Highlights of human toxocariasis
}

\author{
Jean-François MAGNAVAL ${ }^{1 *}$, Lawrence T. GLICKMAN ${ }^{21}$, \\ Philippe DORCHIES ${ }^{31}$ and Bruno MORASSIN ${ }^{11}$
}

\begin{abstract}
Service de Parasitologie ${ }^{1)}$, Centre Hospitalier Universitaire Rangueil 31403 Toulouse 4, France, Department of Veterinary Pathobiology 2), School of Veterinary Medicine, Purdue University, West Lafayette, IN 47907, USA, Laboratoire de Parasitologie3), École Nationale Vétérinaire, 31076 Toulouse, France
\end{abstract}

\begin{abstract}
Human toxocariasis is a helminthozoonosis due to the migration of Toxocara species larvae through human organism. Humans become infected by ingesting either embryonated eggs from soil (geophagia, pica), dirty hands or raw vegetables, or larvae from undercooked giblets. The diagnosis relies upon sensitive immunological methods (ELISA or western-blot) which use Toxocara excretory-secretory antigens. Seroprevalence is high in developed countries, especially in rural areas, and also in some tropical islands. The clinical spectrum of the disease comprises four syndromes, namely visceral larva migrans, ocular larva migrans, and the more recently recognized "common" (in adults) and "covert" (in children) pictures. Therapy of ocular toxocariasis is primarily based upon corticosteroids use, when visceral larva migrans and few cases of common or covert toxocariasis can be treated by anthelmintics whose the most efficient appeared to be diethylcarbamazine. When diagnosed, all of these syndromes require thorough prevention of recontamination (especially by deworming pets) and sanitary education.
\end{abstract}

Key words: Toxocara, toxocariasis, helminthiasis, visceral larva migrans

\section{INTRODUCTION}

Human toxocariasis is a helminthozoonosis due to the infestation of humans by ascarid larvae belonging to the genus Toxocara. The first description was made in the early 1950's, and for many years this helminthiasis was regarded as an uncommon pediatric disease. Since roughly two decades, the availability of sensitive and specific immunodiagnostic tests

- Received 7 November 2000, accepted after revision 7 February 2001.

*Corresponding author Prof. J-F. MAGNAVAL, Service de Parasitologie, Centre Hospitalier Universitaire Rangueil, 31403 Toulouse 4, France. Phone 335613228 90; fax: 3356114 59 72; e-mail: magnaval@cict.fr has greatly improved our knowledge of toxocariasis, which certainly is the most prevalent helminthiasis in industrialized countries.

\section{EPIDEMIOLOGY}

\section{Toxocariasis in the definitive host}

Among nematodes of the genus Toxocara, only two species, Toxocara canis and T. cati, are recognized as causative agents of human disease (Beaver et al., 1952; Nagakura et al., 1990). The adult form of both ascarids live in the upper digestive tract of their definitive hosts, canids and felids, respectively. Female worms may produce up to 200,000 eggs per day. Eggs passed in the feces are not infective and require an incubation period in the soil to embryonate (Glickman and Schantz, 1981). 
Swallowing of infective eggs by adult dogs or cats rarely results in the presence of adult Toxocara worms in the digestive tract. The embryonated eggs hatch in the small intestine where the released larvae perforate the wall. They then enter a blood vessel and go through the liver and lungs to the left heart where they are disseminated by the systemic circulation (somatic migration). Eventually, these larvae penetrate through capillary vessels and migrate to surrounding tissues where they may survive for years without undergoing further development ("hypobiosis"). When a bitch becomes pregnant, the dormant larvae can be reactivated by hormonal stimuli and migrate transplacentally to the fetus (Dubey, 1978). This explains why new-born puppies are likely to be infected. In contrast, transplacental migration of larvae does not occur in cats. The primary route of infection of kittens is by transmammary transmission of larvae that are found in the milk, whereas this type of transmission is less important in dogs (Burke and Robertson, 1985).

Infective eggs that are ingested by non-canid and non-felid species follow a somatic cycle similar to that described above. This leads to the presence of larvae in tissues where they are potentially infective to predators on these animals. This type of transmission is called "paratenesis". When a dog or a cat preys upon an infected paratenic host, the larvae are liberated from the tissues during the digestion process and then complete their development in the intestinal tract (Glickman and Schantz, 1981).

The prevalence of infection of dogs with adult Toxocara worms was reported to be about 25 per cent in Western countries (Barriga, 1988), while the rate in cats in France was 30 to 60 per cent (Petithory et al., 1996). The prevalence of infection tends to decrease with increasing age of the animal and is lower in well-cared pet dogs than in stray or pound dogs. This high prevalence together with the high fecundity of Toxocara, and the increasing number of pet animals in Western countries as well, explain the high level of soil contamination with Toxocara eggs in parks, playgrounds, and other public places. For example, the proportion of soil samples positive for $T$. canis eggs in parks and playgrounds has ranged from 15 to 78 per cent (Barriga, 1988). Recent studies have demonstrated that soil samples taken from gardens of homes where a clinical case of toxocariasis is found, are likely to be contaminated (Magnaval and Baixench, 1993). Toxocara eggs have been recovered from salads and other raw vegetables taken from such gardens (Vazquez et al., 1997).

\section{Toxocariasis in humans}

Human toxocariasis is primarily a soiltransmitted zoonosis. Geophagia or soil eating is a specific type of pica that increases the risk of toxocariasis, especially in children living in homes with puppies that have not been dewormed. Poor personal hygiene as well as consumption of raw vegetables grown in contaminated kitchen gardens may result in chronic low-dose infections. Less commonly, zoonotic toxocariasis infection is associated with consumption of raw meat from potential paratenic hosts, such chickens (Nagakura et al., 1989), lambs (Salem and Schantz, 1992) or rabbits (Sturchler et al., 1990). Among veterinary students in Toulouse (France), the seroprevalence of toxocariasis was significantly higher among persons frequently eating raw or undercooked calf liver than in persons who ate their meat well-done (Baixench et al., 1992). This suggests that infective larvae can be released from animal tissues during digestion and subsequently cause human toxocariasis.

Toxocariasis is one of the most commonly reported zoonotic helminth infections in the world. Seroprevalence surveys in Western countries found that 2 to 5 per cent of apparently healthy adults from urban areas had a positive result compared with 14.2 to 37 per cent of adults in rural areas (Magnaval et al., 1994a). In tropical countries the seroprevalence of Toxocara infection was higher, namely 63.2 per cent in Bali (Chomel et al., 1993), 86 per cent in Saint-Lucia, West Indies, among children (Thompson et al., 1986), and 92.8 per cent in adults in La Reunion (French Oversea Territories, Indian Ocean) (Magnaval et al., 1994b). 


\section{PATHOGENESIS OF HUMAN TOXOCARIASIS}

In humans, after ingestion of embryonated Toxocara eggs, the larvae follow the same somatic route of migration as for paratenic hosts. The hatched larvae have been found in the liver, lungs, heart, eye, and brain (Wilder, 1950; Dent et al., 1956). They are often associated with migratory tracks characterized by hemorrhage, necrosis, and inflammation, with eosinophils predominating. Larvae may become encapsulated within granulomas where they are either destroyed or persist in a viable state for many years. In the eye where the migration of a single larva can be observed, the inflammatory response can lead to partial or total retinal detachment with visual loss (Neafie and Connor, 1976). The host immune responses to migrating larvae appear to be directed against the larval excretory-secretory antigens (TES-Ag). These antigens are released by larvae from their epicuticle, which is readily sloughed off when bound by specific antibodies (Page et al., 1992). The antigens are a mix of glycoproteins including a potent allergenic component (Sugane and Oshima, 1983) which could be similar to the so-called TBA-1 found in adult Toxocara worms.

The mechanism by which larvae in tissues are killed and eliminated is not known. In mice, eosinophils do not appear to be involved in host resistance (Dent et al., 1999), since antibody-dependent cell cytolysis mediated both by eosinophils and specific IgE antibodies is lacking (Jones et al., 1994). Trapping of larvae in the liver during somatic migration as described in mice (Parsons and Grieve, 1990), could play a significant role in the host defense. Indirect evidence suggests that intrahepatic larval destruction also occurs in humans. For example, persons with asymptomatic Toxocara infection and a history of repeated exposure to Toxocara contaminated environments may have a persistent and moderate increase of their $\gamma$-glutamyl transpeptidase serum enzyme level (Magnaval and Baixench, 1993), together with a normal blood eosinophil count and a high antiToxocara antibody titer (Magnaval, unpublished data).

\section{CLINICAL FEATURES}

Advances in the knowledge of the disease demonstrated that Toxocara infection elicits in humans several different syndromes.

\section{Visceral larva migrans}

Visceral larva migrans (VLM) was first described in 1952, in children with an enlarged liver and hypereosinophilia (Beaver et al., 1952). The typical VLM patient is a child between the ages of 2-7 years with a history of geophagia and exposure to puppies in the home. The acute signs of VLM associated with hepatic and pulmonary larval migration often include abdominal pain, decreased appetite, restlessness, fever, coughing, wheezing, asthma, and hepatomegaly. In this phase of the infection, there is usually a marked eosinophilia $\left(>2,000\right.$ cells $\left./ \mathrm{mm}^{3}\right)$, leukocytosis, and hyper-gammaglobulinemia. In Western countries, the VLM syndrome is rarely encountered, and a review of the literature from 1952 to 1979 found only 970 such reports (Ehrard and Kernbaum, 1979).

\section{Ocular larva migrans}

Ocular larva migrans (OLM) typically occurs unilaterally in children and young adults. The most common symptom is visual loss, with onset over a period of days to weeks. Funduscopy and biomicroscopic examination often reveals uveitis, endophthalmitis, papillitis (Gass and Braunstein, 1983), retinal granulomatous lesions (Gillespie et al., 1993), or inflammatory masses (snow-banks) in the peripheral vitreous (Tran et al., 1999). In some individuals these signs may wax and wane over a period of years. Ocular infection may also be subclinical and only detected during a routine eye examination. OLM apparently is an endemic disease in some areas with an estimated incidence of 1 per 100,000 persons in Alabama in the USA (Maetz et al., 1987).

\section{More recently recognized syndromes}

The large discrepancy between the relatively small number of reported cases of VLM and OLM syndromes and the high seroprevalence 
rate, especially in rural areas, led to a search for other clinical manifestations of toxocariasis. Two case-control studies, carried out in adults in France (Glickman et al., 1987) and in children in Ireland (Taylor et al., 1988), were conducted to address this issue.

In French adults, toxocariasis was characterized clinically by weakness, pruritus, rash, difficult breathing, and abdominal pain. Significant laboratory findings included eosinophilia (average 1,444 cells per $\mathrm{mm}^{3}$ ), increased total serum IgE level (average, 851 $\mathrm{IU} / \mathrm{ml}$ ), and elevated antibody titers to $T$. canis. This syndrome was termed "common toxocariasis" in adults (Magnaval et al., 1994a).

In Ireland, the most frequent clinical findings in children infected with Toxocara were fever, anorexia, headache, abdominal pain, nausea, vomiting, lethargy, sleep and behavior disorders, pharyngitis, pneumonia, cough, wheeze, limb pains, cervical lymphadenitis and hepatomegaly. Twentyseven per cent of the patients displaying high anti-Toxocara titers had normal blood eosinophil counts. This form of the disease in children was coined "covert toxocariasis".

It is likely that many persons with these clinical forms of Toxocara infection often go undiagnosed, because the above-cited clinical manifestations and laboratory abnormalities are non-specific. Toxocariasis also has been associated with various allergy-related syndromes including chronic urticaria (Wolfrom et al., 1996), reactive arthritis (Bethel, 1981), or angioedema (Magnaval and Baixench, 1993).

\section{Neurological toxocariasis}

Toxocara larvae readily migrate in the brain of experimentally infected laboratory animals. However, a review of the English literature from 1950 to the present, found less than twenty reports of neurological toxocariasis in humans, as determined by the finding of Toxocara larvae in cerebral spinal fluid (CSF), in brain tissue, in the meninges, and/or by immunodiagnosis on CSF (Wang et al., 1983; Hill et al., 1985; Russegger and Schmutzhard, 1989; Ruttinger and Hadidi, 1991; Kumar and Kimm, 1994; Komiyama et al., 1995; Duprez et al., 1996). As with VLM, the clinical signs of neurological toxocariasis are nonspecific (Magnaval et al., 1997), leading to possible under diagnosis of this condition.

\section{DIAGNOSIS}

\section{Radiology}

Medical imaging techniques can be used to detect and localize granulomatous lesions due to Toxocara larvae. Abdominal ultrasound has shown multiple hypoechoic areas in the livers of 14 children who initially presented with hepatomegaly, eosinophilia and a positive Toxocara serology (Baldisserotto et al., 1999). Using computed tomography (CT), hepatic lesions appear as low-density areas, as shown in Fig. 1 (Dupas et al., 1986; Ishibashi et al., 1992). In the CNS, more sensitive magnetic resonance imaging (MRI) has revealed granulomas appearing as hyper-intense areas on $\mathrm{T}_{2}$-weighted images, primarily located cortically or sub-cortically (Ruttinger and Hadidi, 1991). In 11 patients with OLM, ultrasound has revealed a highly reflective peripheral mass, vitreous bands or membranes, and traction retinal detachment (Wan et al., 1991).

\section{Laboratory diagnosis}

A peripheral blood eosinophilia, although not specific to Toxocara infection, has been constantly associated with VLM. In contrast, in patients with OLM, this laboratory finding is often absent (Glickman and Schantz, 1981), probably due to the low larval burden (often a single larva) in children with OLM. In common and covert toxocariasis, blood eosinophilia can be absent in some patients. Other diagnostic tests should therefore be considered, the most promising of which is determination of the concentration of serum total IgE.

A definitive laboratory diagnosis of human toxocaral infection can be achieved by pathology examination of various organ specimens, including the liver (Kirchner and Altmann, 1987), brain (Hill et al., 1985), lung or enucleated eye (Neafie and Connor, 1976). In the ocular form of the disease, a mobile larva can be directly observed under the retina (Meyer-Riemann et al., 1999). However, such a 


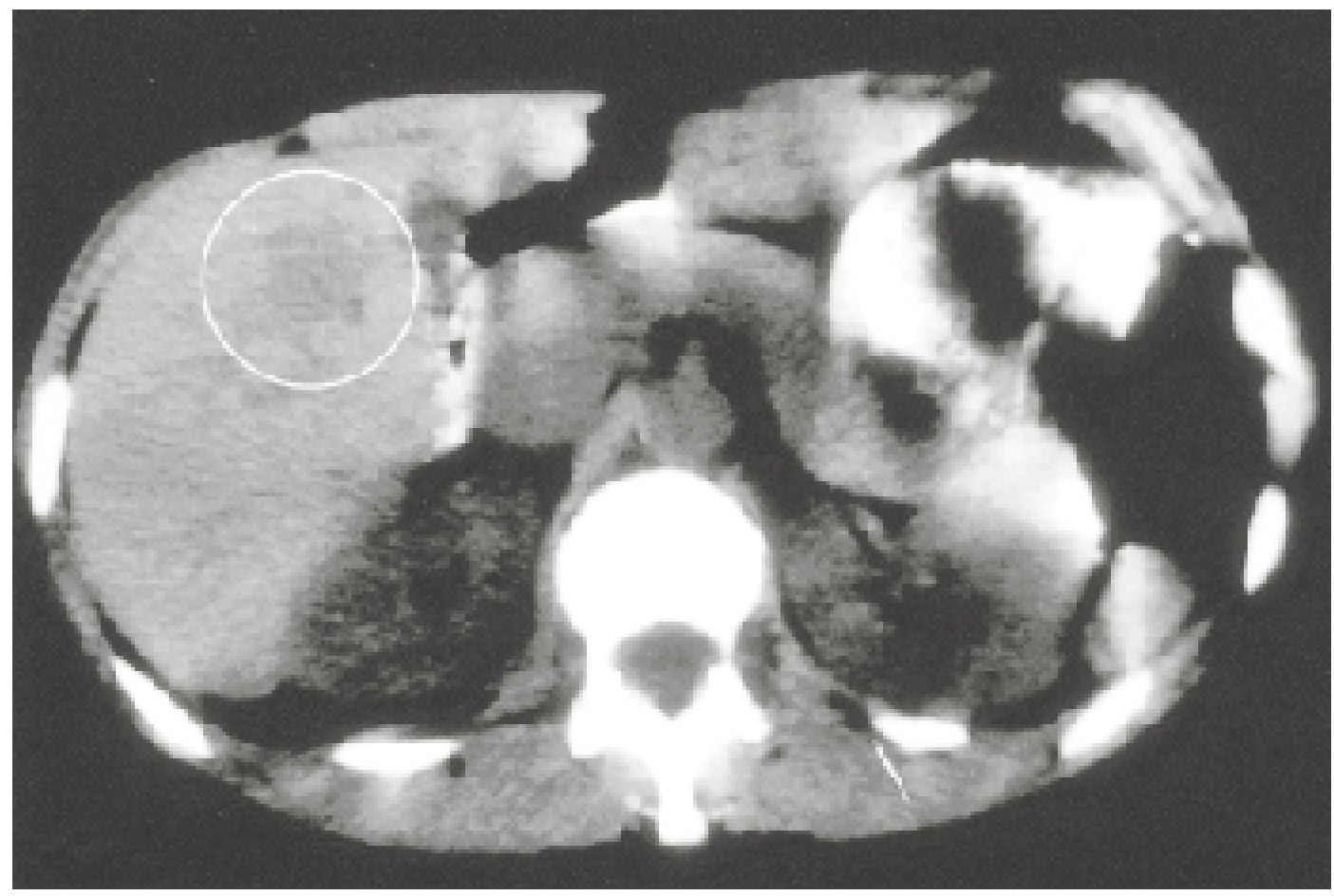

Fig. 1. Liver CT scan showing a low-density area (circled) due to toxocariasis

direct parasitologic assessment is awkward and uncommon, and serologic methods are the mainstay for the diagnosis.

The most commonly utilized diagnostic serologic test is the enzyme-linked immunosorbent assay (ELISA) with TES-Ag (De Savigny et al., 1979). The use of excretorysecretory antigens from $T$. canis larvae maintained in vitro further increases the specificity of the ELISA (Jacquier et al., 1991). A positive ELISA for Toxocara can be confirmed by western blot (WB), which is as sensitive as ELISA, and quite specific when lower molecular weight bands, from 24 to 35 kilodaltons, are considered (Magnaval et al., 1991). A commercial kit is now offered in Europe, displaying excellent results (Fig. 2).

The detection of immunoglobulin isotypes other than IgG can be helpful in the differential diagnosis of toxocariasis. An increase in the serum concentration of $\operatorname{IgE}$ specific for TES-Ag, as measured by radioimmunoassay (Genchi et al., 1988) and ELISA (Magnaval et al., 1992), was reported in patients with clinical signs suggestive of

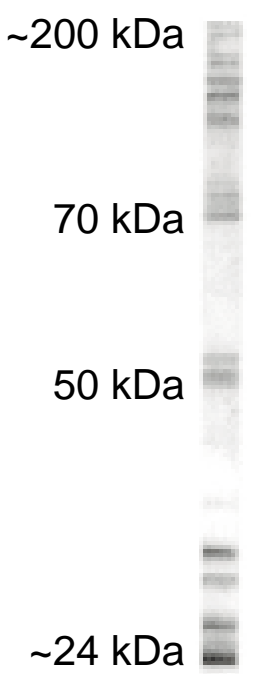

Fig. 2. Positive result yielded by Toxocara Western blot-G kit (LDBIO, Lyon, France)

\section{Toxocara infection.}

The serum ELISA for Toxocara-specific IgG is less sensitive for the diagnosis of OLM than for other forms of the disease (Glickman et al., 
1986). Therefore, aqueous or vitreous fluid should be obtained when ocular toxocariasis is suspected. The anti-Toxocara antibody titer in these fluids has been found to be higher and therefore, more diagnostic than serum obtained from patients with OLM (Brasseur et al., 1984).

When interpreting a serologic result, it should be kept in mind that the numerous seropositive individuals detected through screening of large populations in epidemiological surveys probably represent past rather than recent infection. A single seropositivity therefore has limited pathological significance. Only patients with clinical signs consistent with a Toxocara infection are candidates for therapy, since current immunodiagnostic tests are not capable of distinguishing between current and past infection. Immunologic testing therefore, should be accompanied by a blood eosinophil count and if possible, by determination of serum total IgE.

A finding of both a peripheral eosinophilia and a positive serologic test result is indicative of active toxocariasis. The diagnosis is less certain in individuals who lack eosinophilia but who present with one or more clinical signs of covert toxocariasis. In such cases an increase in the concentration of serum total IgE $>500 \mathrm{IU} / \mathrm{ml}$ is further evidence of recent Toxocara infection. The detection of the eosinophil-cationic-protein (ECP) that is released by activated eosinophils also could be helpful, due to the preferential accumulation of these cells into tissues.

\section{TREATMENT OF TOXOCARIASIS}

\section{Drugs}

Though numerous anthelmintics have been tested in animal models, controlled randomized studies have rarely been conducted in humans, so very few drugs are available for the treatment of the human disease.

Benzimidazole derivatives are thiabendazole (TBZ), mebendazole (MBZ), and albendazole (ABZ), as classified by seniority.

When TBZ was given orally every day in doses of $25 \mathrm{mg} / \mathrm{kg} \mathrm{b} / \mathrm{w}$ (Magnaval and Charlet, 1987) to $50 \mathrm{mg} / \mathrm{kg} \mathrm{b} / \mathrm{w}$ (Bass et al.,
1987; Sturchler et al., 1989) for 3 to 7 days, an improvement in clinical manifestations was found amongst 50 per cent (Magnaval and Charlet, 1987) to 53 per cent (Sturchler et al., 1989) of the patients. Side-effects consisting of dizziness, nausea, and vomiting, were observed in 50 per cent (Magnaval and Charlet, 1987) and 60 per cent (Sturchler et al., 1989) of patients.

Regarding MBZ, the best therapeutic schedule was $20-25 \mathrm{mg} / \mathrm{kg} \mathrm{b} / \mathrm{w}$ daily for 3 weeks, which resulted in 70 per cent reduction in clinical manifestations. Side effects consisting of weakness, dizziness, nausea, abdominal and gastric pain were mild and occurred in 17 per cent of treated individuals (Magnaval, 1995).

With $\mathrm{ABZ}$ given at $10 \mathrm{mg} / \mathrm{kg} \mathrm{b} / \mathrm{w}$ daily for 5 days, a clinical improvement was found in 47 per cent of patients with toxocariasis (Stürchler et al., 1989). Sixty per cent of patients complained about minor side-effects. In spite of these mixed results, a review of the recent literature found numerous anecdotal reports indicating that $\mathrm{ABZ}$ has become a commonly used drug for the treatment of toxocariasis, possibly due its wide availability in most countries.

Both $\mathrm{MBZ}$ and $\mathrm{ABZ}$ are poorly absorbed from the gastrointestinal tract and should be administered with a fatty meal.

Diethylcarbamazine, or DEC, has been the mainstay for filariasis chemotherapy since 1949. The mode of action is complex and still remains partially unknown. In filariases, it includes an enhancement of both the adherence and cytotoxicity of neutrophils and eosinophils to microfilariae (Piessens and Beldekas, 1979), along with an activation of platelets that release free radicals. This action is antibody independent and triggered by a filarial excretory antigen (Cesbron et al., 1987). Moreover, DEC interferes with arachidonic acid metabolism and causes production of PGE2, PGE12, and thromboxane, in both the filarial parasite and its host (Martin et al., 1997).

In a controlled randomized study versus MBZ, DEC was given at 3-4 $\mathrm{mg} / \mathrm{kg} \mathrm{b} / \mathrm{w}$ daily for 21 days. The therapeutic schedule started at $25 \mathrm{mg}$ daily and the dose was progressively 
increased in an attempt to avoid adverse reactions due to parasite lysis. No antihistamine drugs were used. This regimen resulted in a 70 per cent significant decrease in the severity of clinical signs. Twenty-eight per cent of patients reported minor side-effects including increased weakness, dizziness, nausea, vomiting, or abdominal pain. These disturbances were dose-dependent and waned when the daily dosage was tapered. In 10 per cent of subjects, a Mazzotti-like reaction (itching, urticaria, and/ or edema) was observed, suggestive of accelerated larval lysis (Magnaval, 1995).

Ivermectin has been shown to be highly effective and improve significantly the prognosis for people with onchocerciasis, the cause of river blindness (Boussinesq et al., 1997). Ivermectin has also been recently registered in the European Union and the USA for treating strongyloidiasis (Marti et al., 1996). Regarding toxocariasis, no controlled study of its efficacy has been conducted. When tested on a series of 17 cases of common toxocariasis, ivermectin was only 40 per cent effective in reducing clinical manifestations, and there was no significant decrease in the blood eosinophil count (Magnaval, 1998). Thus, ivermectin should not be used for the treatment of human toxocariasis, especially OLM, until the question of its efficacy has been thoroughly evaluated.

Whether a person with toxocariasis is a candidate for treatment, depends on the type and severity of clinical signs. Acute VLM in children and adults is usually treated either symptomatically or with specific anthelmintic therapy. Patients presenting with common toxocariasis (Glickman et al., 1987; Magnaval et al., 1994a), or covert toxocariasis (Taylor et al., 1988) along with a peripheral eosinophilia, are often treated conservatively, since these forms of the disease are usually self-limiting. Anthelmintic treatment is therefore not started immediately, but might be considered for patients who remain symptomatic despite efforts to prevent re-infection with Toxocara eggs. Asymptomatic subjects presenting with a chronic eosinophilia and those with covert toxocariasis in the absence of eosinophilia, do not normally require any specific therapy.
Regarding OLM, no controlled clinical trials have been conducted to date for the treatment of this form of the disease. However, anecdotal and case reports (Dinning et al.,1988; Gillespie et al., 1993; Glickman and Magnaval, 1993; Lobovska and Zackova, 1994; Saint-Blancat et al., 1997; Dietrich et al.,1998) suggest that the use of corticosteroids to reduce inflammation is effective and may minimize permanent ocular damage caused by the local release of TES-Ag from larval migration in the eye. The usual regimen is approximately $1 \mathrm{mg} / \mathrm{kg} \mathrm{b} / \mathrm{w}$ daily for 1 month or more, if needed, then the dosage is tapered. Among physical methods, laser photocoagulation is indicated when a larva can be identified by direct visualization in the eye (Gass and Braunstein, 1983; Casella et al., 1998). Ocular granulomas can be treated with cryopexy (El Matri et al.,1990; Zygulska et al., 1993). Pars plana vitrectomy can be used to remove the epiretinal as well as the subretinal component of a Toxocara retinal granuloma (Werner et al., 1999). Should the use of oral and/or topical corticosteroids not result in full recovery, specific anthelmintic treatment should be considered. Whether the benzimidazole derivatives or their active metabolites penetrate well into the human eye has not been established. Further circumstantial evidence regarding penetration of this DEC into the eye comes from experience gained with its wide-spread use for the treatment of human onchocerciasis (Dadzie et al., 1987). Therefore DEC might be the better choice for treating OLM. Since the action of DEC may be inhibited by corticosteroids (Maizels and Denham, 1992), both drugs should not be given together.

The treatment of patients with neurological toxocariasis has consisted of a combination of corticosteroids and DEC (Komiyama et al., 1995), or MBZ (Duprez et al., 1996), or TBZ (Kumar and Kimm, 1994), or the use of DEC (Ruttinger and Hadidi, 1991) or TBZ alone (Russegger and Schmutzhard, 1989; Wang et al., 1983). The results of these studies have been equivocal.

\section{Post-treatment follow-up}

For post-treatment follow-up - OLM excepted -, only eosinophil count appears helpful. In 
a controlled trial of toxocariasis comparing DEC with MBZ, both induced a significant decrease in the mean eosinophil count within 1 month of treatment, whereas the serum total IgE concentration remained unchanged (Magnaval, 1995).

The detection of specific anti-Toxocara IgG by ELISA does not appear to be useful for monitoring therapy. When ELISA antibody titers were compared between treated and untreated children, the kinetics of specific anti Toxocara IgG was not affected by anthelmintic treatment (Bass et al., 1987). Conversely, the specific anti-Toxocara IgE serum concentration does seem to decrease significantly posttreatment if it is markedly elevated prior to therapy (Magnaval et al., 1992), especially in atopic patients.

\section{PROPHYLAXIS}

Whatever the clinical form of toxocariasis encountered, measures must be initiated to prevent reinfection, especially of children. The first step is to obtain a careful history to identify possible environmental and personal risk factors, especially the source of Toxocara eggs, behaviors such as geophagia or poor personal hygiene, and lack of adequate parental supervision. Toxocariasis patients, and also parents of affected children, should be then counseled about the risk factors for toxocariasis.

Any roundworm infected dogs or cats should be immediately dewormed, and contaminated soil removed, or the area closed so it is not accessible to children. Puppies should be routinely treated starting at 2 to 3 weeks of age (Harvey et al., 1991). Further treatment should be given every two weeks until 12 weeks of age (Soulsby, 1987) to minimize environmental contamination with eggs. Adult cats and dogs should be treated two times a year. Treatment of bitches is also indicated after each estrus cycle.

Home-gardens should be fenced to prevent fecal contamination by dogs and cats. Vegetables and salads gathered from possibly contaminated gardens should be thoroughly washed and the consumption of raw or undercooked meat that could harbor Toxocara larvae should be avoided. Geophagia should be brought to the attention of an appropriate health provider for treatment. Personal hygiene also should be upgraded by encouraging handwashing, especially prior to eating and discouraging hand to mouth activity at all times. Municipal ordinances to prevent pet dogs from entering parks and playgrounds and requiring owners to remove their pet's feces from public areas should be considered.

\section{REFERENCES}

Baixench MT, Magnaval J-F, Dorchies P (1992) Epidémiologie de la toxocarose chez les étudiants de l'Ecole Nationale Vétérinaire de Toulouse. Rev Med Vet 143: 749-752.

Baldisserotto M, Conchin CF, Da Soares MG, Araujo MA, Kramer B (1999) Ultrasound findings in children with toxocariasis: report on 18 cases. Pediatr Radiol 29: 316-319.

Barriga OO (1988) A critical look at the importance, prevalence and control of toxocariasis and the possibilities of immunological control. Vet Parasitol 29: 195234.

Bass JL, Mehta KA, Glickman LT, Blocker R, Eppes BM (1987) Asymptomatic toxocariasis in children: a prospective study and a treatment trial. Clin Pediatr 26: 441-446.

Beaver PC, Snyder CH, Carrera GM (1952) Chronic eosinophilia due to visceral larva migrans. Pediatrics 9: 7-19.

Bethel RG (1981) Arthritis and arthralgia associated with toxocaral infestation. $\mathrm{Br}$ Med J 283: 729 .

Boussinesq M, Prod'hon J, Chippaux JP (1997) Onchocerca volvulus: striking decrease in transmission in the Vina valley (Cameroon) after eight annual large scale ivermectin treatments. Trans Roy Soc Trop Med Hyg 91: 82-86.

Brasseur G, Charlin JF, Brasseur P, Langlois J (1984) Toxocarose oculaire. Acquisitions diagnostiques et thérapeutiques. $J \mathrm{Fr}$ Ophtalmol 7: 221-226.

Burke TM, Roberson EL (1985) Prenatal and lactational transmission of Toxocara canis and Ancylostomum caninum. Experimental infection of the bitch before pregnancy. Int $J$ Parasitol 15: 71-75.

Casella AM, Farah ME, Belfort R Jr. (1998) 
Antihelminthic drugs in diffuse unilateral subacute neuroretinitis. Am J Ophthalmol 125: 109-111.

Cesbron J, Capron A, Vargaftig B, et al. (1987) Platelets mediate the action of diethylcarbamazine on microfilariae. Nature 325: 533-536.

Chomel BB, Kasten R, Adams C, et al. (1993) Serosurvey of some major zoonotic infections in children and teenagers in Bali, Indonesia. Southeast Asian J Trop Med Public Health 24: 321-326.

Dadzie KY, Bird AC, Awadzi K, Schulz-Key H, Gilles HM, Aziz MA (1987) Ocular findings in a double-blind study of ivermectin versus diethylcarbamazine versus placebo in the treatment of onchocerciasis. $\mathrm{Br} J$ Ophthalmol 71: $78-85$.

De Savigny DH, Voller A, Woodruff AW (1979) Toxocariasis: serological diagnosis by enzyme immunoassay. $J$ Clin Pathol 32: 284-288.

Dent DH, Nichols RL, Beaver PC, Carrera GM, Staggers RJ (1956) Visceral larva migrans with case report. Am J Pathol 32: 777-803.

Dent LA, Daly CM, Mayrhofer G, et al. (1999) Interleukin-5 transgenic mice show enhanced resistance to primary infections with Nippostrongylus brasiliensis but not primary infections with Toxocara canis. Infect Immun 67: 989-993.

Dietrich A, Auer H, Tittl M, Barisani-Asenbauer T (1998) Okulare Toxokarose in Osterreich. Deutsch Med Wochenschr 123: 626-630.

Dinning WJ, Gillespie SH, Cooling RJ, Maizels RM (1988) Toxocariasis: a practical approach to management of ocular disease. Eye 2: 580582.

Dubey J (1978). Patent Toxocara canis infection in ascarid naive dogs. $J$ Parasitol 64: 10211023.

Dupas B, Barrier J, Barre P (1986) Detection of Toxocara by computed tomography. $\mathrm{Br} J$ Radiol 59: 518-519.

Duprez TPJ, Bigaignon G, Delgrange E, et al. (1996) MRI of cervical cord lesions and their resolution in Toxocara canis myelopathy. Neuroradiology 38: 792-795.

Ehrard T, Kernbaum S (1979) Toxocara canis et toxocarose humaine. Bull Inst Pasteur 77: 225-287.

El Matri L, Ghorbal M, Ayadi A, Ben Naceur B, Triki MF (1990) Localisation oculaire à Toxocara canis apparemment bilaterale. $J \mathrm{Fr}$ Ophtalmol 13: 303-308.
Gass JD, Braunstein RA (1983) Further observations concerning the diffuse unilateral subacute neuroretinitis syndrome. Arch Ophthalmol 101: 1689-1697.

Genchi C, Falagiani P, Riva G, et al. (1988) IgE and IgG antibodies in Toxocara canis infection. A clinical evaluation. Ann Allergy 61: $43-46$.

Gillespie SH, Dinning WJ, Voller A, Crowcroft NS (1993) The spectrum of ocular toxocariasis. Eye 7: 415-418.

Glickman LT, Schantz PM (1981) Epidemiology and pathogenesis of zoonotic toxocariasis. Epidemiol Rev 3: 230-250.

Glickman LT, Schantz PM, Grieve RB (1986) Toxocariasis. In Immunodiagnosis of Parasitic Diseases, volume 1: Helmintic diseases, Walls KW, Schantz PM (eds.). pp201-231 New-York: Academic Press, NYC, USA.

Glickman LT, Magnaval J-F, Domanski LM (1987) Visceral larva migrans in French adults. A new disease syndrome? Am $J$ Epidemiol 125: 1019-1033.

Glickman LT, Magnaval JF (1993) Zoonotic roundworm infections. Infect Dis Clin North Am 7: 717-732.

Harvey JB, Roberts JM, Schantz PM (1991) Survey of veterinarians' recommendations for treatment and control of intestinal parasites in dogs: public health implications. $J$ Am Vet Med Assoc 199: 702-707.

Hill IR, Denham DA, Scholtz CL (1985) Toxocara canis larvae in the brain of a British child. Trans Roy Soc Trop Med Hyg 79: 351-354.

Ishibashi H, Shimamura R, Hirata Y, Kudo J, Onizuka H (1992) Hepatic granuloma in toxocaral infection: role of ultrasonography in hypereosinophilia. J Clin Ultrasound 20: 204210.

Jacquier P, Gottstein B, Stingelin Y, Eckert, J (1991) Immunodiagnosis of toxocariasis in humans: evaluation of a new enzyme-linked immunosorbent assay. J Clin Microbiol 29: 1831-1835.

Jones RE, Finkelman FD, Hester RB, Kayes SG (1994) Toxocara canis: failure to find IgE receptors (Fc epsilon $\mathrm{R}$ ) on eosinophils from infected mice suggests that murine eosinophils do not kill helminth larvae by an IgE-dependent mechanism. Exp Parasitol 78: 64-75.

Kirchner T, Altmann HW (1987) Parasitenlarven als Ursache umschriebener Leberherde. Morphologie und Differentialdiagnose. 
Pathologe 8: 31-36.

Komiyama A, Hasegawa O, Nakamura S, Ohno S, Kondo K (1995) Optic neuritis in cerebral toxocariasis. J Neurol Neurosurg Psychiatry 59: 197-198.

Kumar J, Kimm J (1994) MR in Toxocara canis myelopathy. AJNR Am J Neuroradiol 15: 1918-1920.

Lobovska A, Zackova M (1994) Ocni forma larvalni toxokarozy. Cesk Oftalmol 50: 186190.

Maetz HM, Kleinstein RN, Federico D, Wayne J (1987) Estimated prevalence of ocular toxoplasmosis and toxocariasis in Alabama. $J$ Infect Dis 156: 414.

Magnaval J-F (1995) Comparative efficacy of diethylcarbamazine and mebendazole for the treatment of human toxocariasis. Parasitology 110: 529-533.

Magnaval J-F (1998) Apparent weak efficacy of ivermectin for treatment of human toxocariasis. Antimicrob Agents Chemother 42: 2770.

Magnaval J-F, Baixench MT (1993) Toxocariasis in the Midi-Pyrénées region. In Toxocara and toxocariasis, Lewis JW, Maizels RM (eds). pp63-69 British Society for Parasitology, London, UK.

Magnaval J-F, Charlet J-P (1987) Efficacité comparée du thiabendazole et du mébendazole dans le traitement de la toxocarose. Therapie 42: 541-544.

Magnaval J-F, Fabre R, Maurieres P, Charlet J-P, De Larrard B (1991) Application of the western-blotting procedure for the immunodiagnosis of human toxocariasis. Parasitol Res 77: 697-702.

Magnaval J-F, Fabre R, Maurieres P, Charlet J-P, De Larrard B (1992) Evaluation of an immunoenzymatic assay detecting specific anti-Toxocara immunoglobulin $\mathrm{E}$ for the diagnosis and the post-treatment follow-up of toxocariasis. J Clin Microbiol 30: 2269-2274.

Magnaval J-F, Galindo V, Glickman LT, Clanet M (1997) Human Toxocara infection of the central nervous system and neurological disorders: a case-control study. Parasitology 115: 537-543.

Magnaval J-F, Glickman LT, Dorchies Ph (1994a) La toxocarose, une zoonose helminthique majeure. Rev Med Vet 145: 611-627.

Magnaval J-F, Michault A, Calon N, Charlet JP (1994b) Epidemiology of human toxocariasis in La Reunion. Trans Roy Soc Trop Med Hyg
88: $531-533$.

Maizels RM, Denham DA (1992) Diethylcarbamazine (DEC): immunopharmacological interactions of an anti-filarial drug. Parasitology 105: S49-S60.

Marti H, Haji HJ, Savioli L, et al. (1996) A comparative trial of a single-dose ivermectin versus three days of albendazole for treatment of Strongyloides stercoralis and other soil-transmitted helminth infections in children. Am J Trop Med Hyg 55: 477-481.

Martin RJ, Robertson AP, Bjorn H (1997) Target sites of anthelmintics. Parasitology 114: S111-S124.

Meyer-Riemann W, Petersen J, Vogel M (1999) Extraktionsversuch einer intraretinalen Nematode im papillomakularen Bundel. Klin Monatsbl Augenheilkd 214: 116-119

Nagakura K, Tachibana H, Kaneda Y, Kato Y (1989) Toxocariasis possibly caused by ingesting raw chicken. J Infect Dis 160: 735736.

Nagakura K, Kanno S, Tachibana H, Kaneda Y, Ohkido M, Kondo K, Inoue H (1990) Serologic differentiation between Toxocara canis and Toxocara cati. J Infect Dis 162: 1418-1419.

Neafie RC, Connor DH (1976) Visceral larva migrans. In Pathology of tropical and extraordinary diseases, Binford $\mathrm{CH}$, Connor DH (eds). pp433-436, Armed Forces Institute of Pathology, Washington DC, USA.

Page AP, Rudin W, Fluri E, Blaxter ML, Maizels RM (1992) Toxocara canis: a labile antigenic surface coat overlying the epicuticle of infective larvae. Exp Parasitol 75: 72-86.

Parsons JC, Grieve RB (1990) Kinetics of liver trapping of infective larvae in murine toxocariasis. J Parasitol 76: 529-536.

Petithory JC, Vandemeulebroucke E, Jousserand P, Bisognani AC (1996) Prevalence de Toxocara cati chez le chat en France. Bull Soc Fr Parasitol 14: 179-184.

Piessens W, Beldekas M (1979) Dietylcarbamazine enhances antibody-mediated cellular adherence to Brugia malayi microfilariae. Nature 282: 845-847.

Russegger L, Schmutzhard E (1989) Spinal toxocaral abscess. Lancet ii: 398.

Ruttinger P, Hadidi H (1991) MRI in cerebral toxocaral disease. J Neurol Neurosurg Psychiatry 54: 361-362.

Saint-Blancat P, Morand I, Clabaut FX, Boissonnot M, Risse JF (1997) Toxocarose à Toxocara canis Deux cas de granulome 
peripherique chez l'adulte. $J$ Fr Ophtalmol 20: 252-257.

Salem G, Schantz P (1992) Toxocaral visceral larva migrans after ingestion of raw lamb liver. Clin Infect Dis 15: 743-744.

Soulsby EJL (1987) Larva migrans in perspective. In Helminths Zoonoses, Geerts S, Kumar V, Brandt J (eds.). pp137-149 Martinus Nijhoff, La Haye, The Netherlands.

Sturchler D, Schubarth P, Gualzata M, Gottstein B, Oettli A (1989) Thiabendazole vs. albendazole in treatment of toxocariasis: a clinical trial. Ann Trop Med Parasitol 83: 473478.

Stürchler D, Weiss N, Gassner M (1990) Transmission of toxocariasis. $J$ Infect Dis 162: 571-572.

Sugane K, Oshima T (1983) Purification and characterization of excretory and secretory antigen of Toxocara canis larvae. Immunology 50: 113-120.

Taylor M, Keane C, O' Connor P, Mulvihill E, Holland C (1988) The expanded spectrum of toxocaral disease. Lancet i: 692-695.

Thompson DE, Bundy DAP, Cooper ES, Schantz PM (1986) Epidemiological characteristics of Toxocara canis infection of children in a Carribean community. Bull WHO 64: 283290.

Tran VT, Lumbroso L, LeHoang P, Herbort CP
(1999) Ultrasound biomicroscopy in peripheral retinovitreal toxocariasis. Am $J$ Ophthalmol 127: 607-609.

Vazquez TO, Martinez BI, Tay ZJ, Ruiz HA, Perez TA (1997) Verduras de consumo humano como probablo fuente de infeccion de Toxocara sp. para el hombre. Bol Chil Parasitol 52: 47-50.

Wan WL, Cano MR, Pince KJ, Green R (1991) Echographic characteristics of ocular toxocariasis. Ophthalmology 98: 28-32.

Wang C, Huang CY, Chan PH, Preston P, Chau PY (1983) Transverse myelitis associated with larva migrans. Finding of a larva in cerebrospinal fluid. Lancet i: 423.

Werner JC, Ross RD, Green WR, Watts JC (1999) Pars plana vitrectomy and subretinal surgery for ocular toxocariasis. Arch Ophthalmol 117: 532-534.

Wilder HC (1950) Nematode endophthalmitis. Trans Am Acad Ophthalmol Otolaryngol 55: 99-109.

Wolfrom E, Chene G, Lejoly-Boisseau H, Beylot C, Geniaux M, Taieb A (1996) Urticaire chronique et Toxocara canis. Etude castemoins. Ann Dermatol Venereol 123: 240246.

Zygulska-Mach H, Krukar-Baster K, Ziobrowski S (1993) Ocular toxocariasis in children and youth. Doc Ophthalmol 84: 145-154. 